\title{
A Comparative Study of English and Chinese Animal Proverbs_-From the Perspective of Metaphors
}

\author{
Jianwen Liu \\ School of Foreign Languages, Wuhan Polytechnic University, Wuhan, China
}

\begin{abstract}
Proverbs, in nature, are greatly associated with culture. In both form and meaning, they are concise and comprehensive, vivid in images and select materials widely, delivering all sorts of physiological information and cultural knowledge and explicitly expressing all human beings' life, social and historical experience. Since the ancient time, animals have been the most intimate friend of human beings, and people intend to express their feelings and points of view on animals. Therefore, some animal words are added with people's feelings and associations, human beings often deliver ideas and feelings through animals. There are lots of animal proverbs in English and Chinese. Metaphor is ubiquitous. It is not only a rhetorical device but also a mode of thoughts. There are some similarities and differences in animal proverbs' metaphor because of the similar and different faith, value, and ways of thinking and aesthetic orientation. I will make a comparative and contrastive analysis of metaphorical meanings between English and Chinese proverbs and compare some representative animal proverb metaphors. This study is carried out from three main aspects: the same animal produce the same association and metaphorical meaning; the same animal produce different emotions and associations; different animals produce the same association and metaphorical meaning.
\end{abstract}

Index Terms - Chinese, English, animal proverbs, metaphor

\section{INTRODUCTION}

\section{A. Major Views of Metaphor}

What is metaphor? In the traditional conceptions, metaphor is just a kind of language phenomenon, which is used to decorate utterance. From the angle of rhetoric, it is a figure of speech and misplacement of an ornamental device used in rhetorical style. In the opinions of logicians, it is categories. From the understanding of cognitive scientists, it is a way for people to recognize the world. In the eyes of cognition linguists, it is not only a kind of language phenomenon, but also cognition activities, as well as human's basic instrument of cognition...

\section{Aristotle's view of metaphor}

When it comes to metaphor, the first person we need to mention is Aristotle. His Metaphorical Comparison, which established the foundation for the next 2000 years' research, is referred as the first systematically theatrical research related to metaphor phenomenon.

Aristotle (1954) holds that metaphor is a comparison or similarity between two or more objects that do not belong to the same category, and he takes all similes as metaphors. Aristotle sees metaphor as a kind of decoration addition to ordinary plain language, and a rhetorical device which is used at certain times to gain certain effects. From the view of Aristotle, metaphor is something outside normal language and requires special forms of interpretation from listeners or readers. It is often seen as a departure from literal language.

\section{Richards'view of metaphor}

The study of metaphor had developed greatly after 1930s. The publication of The Meaning of Meaning and The Philosophy of Rhetoric by I. A. Richards had made a difference in the metaphor. Richards defines metaphor that "In the simplest formulation, when we use a metaphor, we have two thoughts of different things active together and supported by a simple word, or phrase, whose meaning is the resultant of their interaction." (Richards, 1936, p.28) He did not consider a metaphor as a figure of speech, but a combination of general ideas. Richards (1936) presented that metaphors are special use of linguistic expressions where one metaphorical expression is embedded in another literal expression, and in this way, the meaning of metaphorical expression interacts with and changes the meaning of the literal expression vice versa. Therefore, his study made it possible for people to understand the semantic structure of metaphors.

\section{Lakoff and Johnson's view of metaphor}

Metaphor exists everywhere in our daily life, not only in languages, also in our thoughts and behavior. The conceptual system that we are used to think and act is also metaphorical in nature. Also the linguist Shu Dingfang (2011) in China points out that metaphor can be found everywhere, and it is used in one in three of our daily oral communication in average.

The publication of Lakoff and Johnson's influential work Metaphors We Live By marked the real beginning of cognitive metaphor study. The main concern of conceptual metaphor is that "metaphor is not just a matter of language, 
that is, of mere words; we argue that, on the contrary, human thought processes are largely metaphorical" (Lakoff and Johnson, 2003, p.4).

Metaphor is a prevalent phenomenon that lies in our daily language and structures our daily life. And metaphor is conceptual in nature: it is a figure of thought, a conceptual or cognitive organization which is expressed by linguistic object rather than a figure of speech, a linguistic object. Metaphor is a way of thinking and a cognitive device. They also hold that metaphor is systematically grounded in human cognition, one common metaphorical concept will give rise to numerous linguistic expressions: different metaphorical concepts form a coherent network which underlines both our speech and our thoughts. There are two domains in metaphor. One is source domain and another is target domain. It is a mapping of the schematic structure of the source domain onto that of the target domain, and metaphorical mappings are not arbitrary but are grounded in our bodily experience. Once a metaphorical mapping is set up, it will then impose its structures on real life and be made real in different ways. Language is based on our experiences of the world and the way we perceive and conceptualize it. Experience is a product of interaction of our body with the outside world (including notions, living things, etc) or interactions between us and physical environment or other people within our culture, all of which constitute our conceptual system. And most of our abstract concepts are understood through other concrete or simple ones by mapping the properties of one domain onto another.

\section{B. Definition of Proverb}

It is not an easy job to define a proverb. Here are the several definitions:

(Proverb) is a brief familiar maxim of folk wisdom, usually compressed in form, often involving a bold image and frequently a jingle that catches the memory._L Longman Modern English Dictionary

(Proverb) is a short saying in common and recognized use; a concise sentence, often metaphorical or alliterative in form, which is held to express some truth ascertained by experience or observation and familiar to all.— $—$ The Oxford English Dictionary

(Proverb) is an old or common saying especially, a sentence which briefly and forcibly express some practical truth, or the result of experience and observation._Unabridged Dictionary

Among them, Longman Modern English Dictionary shows us the best definition. The definition of proverb in Chinese is more difficult than that in English, because Chinese idioms are categorized into more sophisticated types. And we can try to get some characters of proverbs in Chinese: Proverb is one of idioms in Chinese, which are popular folk sayings in fixed form and colloquial in language. They are idiomatic expressions which convey wisdom, counsel or warning in a straightforward way, they are widespread popular among the common people. Proverbs compose of a couplet clause to form rhyme and parallels. As proverbs are usually independent sentences, they are instructive, philosophic, informative and inspiring.

\section{COMParative ANAlysis OF The Proverbs}

As we know, many animal proverbs can be found. But some animal proverbs do not have metaphorical meaning, such as in Chinese “犬守夜，鸡司晨” and in English “every time the sheep bleats it loses a mouthful”. And this thesis mainly concerns the animal proverbs with their metaphorical meanings. In this article, the author divides the animals into three types. The first type includes animals which are identical in both animal images and meanings; the second type includes animals which are identical in animal images but meanings; the third type includes animals which are identical in meanings but animal images.

\section{A. Identical in Both Animal Images and Meanings}

Though there are different cultural backgrounds in oriental and western countries, every nation share the same view and feelings towards our objective world, and people get the same conclusion based on their similar experience, meanwhile, one animal owns the same property. So, from this perspective, people use the same animals to express the same metaphorical meanings in both English and Chinese. Some animal proverbs in English and Chinese are identical in both form and meaning. The proverbs in this category are limited in number. They are the result of either coincidence or translation loans from one language to another. These proverbs are not hindered by national boundaries or cultural barriers, instead they have taken some universal significance. For example, evil people, flaw, disable people, sly people and timid people are mice; danger, difficult situation, and ferocious people are tigers; villain or scoundrel people and weak people are hares; craft, cunning people are snakes; docile people who do not have their own idea are sheep; wicked people and bad people are dogs; and worthless people or objects are pigs. Here are some examples:

1a. 老鼠爱打洞，坏人爱钻空老鼠怕见猫儿. The mouse does not trust to one hole only.

In example 1a, 鼠 mouse/rat ,means: timid,shortsighted

$\underline{1 b}$. 一颗老鼠屎坏了一锅汤. A speck of mouse dung will spoil a whole pot of porridge.

Flaw is mouse

2a. 老虎的屁股摸不得 伴君如伴虎. A tiger does not have to proclaim its tigri-tude.

In example 2a, 虎 tiger , means: danger, ferocious

2b. 不入虎穴, 焉得虎子. If you don't enter a tiger's den, you can't get his cubs. 
Danger is tiger

2c. 关门养虎, 虎大伤人. If you raise a tiger secretly behind closed doors, when the tiger grows up it will harm you or others.

Bad people are tigers

3a. 兔子不急不咬人 兔子不吃窝边草

If you run after two hares, you will catch neither. Seek a hare in a hen's nest

In example $\underline{3 \mathrm{a}}$, 兔 rabbit/hare , means: weak, docile, villain or scoundrel people are hares.

4a. 蛇走无声, 奸计无影 蛇不打死害众人，虎不打死留祸

Warm a snake in one's bosom

In example $\underline{4 a}$, 蛇 snake , means: evil, bad

5a. 羊毛出在羊身上 羊入虎口，有去无回

Lone sheep is in danger of the wolf

In example 5a, 羊 sheep/lamb, means: mild-temper, timid

5b. 羊群走路, 看头羊. If one sheep leap over the dyke, all rest will follow.

People who do not have their own ideas are sheep.

6a. 人生不读书, 活着不如猪. 死猪不怕开水惣

What can you expect from a pig but a grunt?

In example $\underline{6 \mathrm{a}}$, 猪 pig, means: fool, dirty and ugly, worthless people are pigs.

7a. 狗改不了吃屎. The dog returns to his vomit.

In example 7a, 狗 dog, means: bad people are dogs.

The above seven examples show us that every pair of proverb not only has the same animal images, literal meanings, but also with the same metaphorical meanings.

1. Metaphorical meanings related to wolf

As we know, wolf often reflects ferocious in both English and Chinese. For example:

8a. 狼走千里吃人; 狼肚子里没有好心肝

$\underline{8 \mathrm{~b}}$. The wolf may lose his teeth, but never his nature. $\quad$ 8c. Man is to man either a god or a wolf.

Wolves are very strong animals. From the perspective of their habits, they can work in cooperation with a due division of labor well, knowing the meaning of unity and obedience. However, people magnify wolves' ferocious towards their enemy and their greedy. And it has become the typical cognition to wolf. As the proverb says $a$ wolf may change his hair, but not his heart. Though different nations are situated in different regions, so are their components, wolf always play a negative role in most culture, either in "Little Red" of Western story or in the idiom "A wolf work hand in glove with a jackal". Wolf is the source domain, and it is given ferocious meaning in the target domain, thus their negative figures are inflexible when reflecting to human.

\section{Metaphorical meanings related to bee}

Bee often represents busy and hard-working. In the proverbs 9a. 蜜蜂酿蜜，不为己食; 9b. 蜂采百花酿甜蜜; 9c. She is always as busy as a bee; The bee works in the summer and eats honey all the winter, people express their favorable impressions towards bees. Despite bees' behavior are instinct reaction, human elevating it as moral force, thus bees and their spirits make up a complete cognition process. It is a consensus for Western and Chinese people that bees' diligence and hard-working reflects human's selfless service in target domain.

Many factors have contributed to the emergence of fully corresponding pairs in English and Chinese Proverbs.

Firstly, although different nations live in varied natural environments and diversified geographic conditions, they still share quite a lot in common. They have more or less the same species of animals. And the common ground of human culture is larger than the individual features of each culture. Although, people's concrete ways of life are varied in different places, the fundamental ways of living and thinking are the same for the whole human race.

Secondly, owing to cultural exchange, translation loans are borrowed from each other, which are not limited to the root ideas but sometimes include the "clothing of the idea". As a result, some proverbs with identical form and meaning come into existence in different language, for instance, $\underline{10 \mathrm{a}}$. “He who rides tiger is afraid to dismount” and “骑虎难下”.

\section{B. Identical in Animal Images But Different in Meanings}

Language is not only the mirror of culture, reflecting culture, but also influenced and restricted by culture. No matter in which country or area, their languages all contain love and hatred in emotional coloring. People share the different opinions towards the same thing, though expressing manners are varied. In the process of human development, China and Britain have many of the same animals. But because of their difference in cultural background, moral concept, thinking mode, and especially in geographic environment, these animals play a very different role in the two countries. People with different cultural background often entrust the same feeling or trait to different animals, cultivating their unique nationalities. So, from this perspective, people use the same animals to express different metaphorical meanings in English and Chinese.

\section{Proverbs of dragon}

Dragon has a long history in China, In Chinese ancient legend, dragon is a holy animal. It is the spiritual symbol of 
the Chinese nation. Chinese people called themselves descendant of the dragon. It has been considered to be powerful people, and the emperors always thought they were real dragon and the sons of the heaven, thus dragon had been the symbol of power and nobility. In the proverbs 11a. 恶龙难斗地头蛇-Even a fierce dragon is hard to put struggle against a local snake, powerful people are dragons. And in the proverb $11 \mathrm{~b}$. 龙生龙, 凤生凤, 老鼠的儿子会打洞。 -- Phoenixes beget phoenixes and dragons beget dragons, so the son of rats is capable of digging holes; people who are in high status are dragons. As dragon can do anything it wants to do, it is also called excellent people, as the proverb says 11c. 龙眼识珠, 凤眼识宝, 牛眼识青草。-- A dragon's eyes can recognize pearls; a phoenix's eyes can see treasures, and an ox's eyes know what kind of grass is edible. According to the legend, dragons could fly above the clouds and control the forces of nature, creating favorable weather for the crops. For example, $11 \mathrm{~d}$. 龙行一步，百草皆 春。-- Dragons move one step and all the grasses will become green. Therefore, in Chinese culture, dragon is a positive reflection.

While in Western countries, dragon is seen as dangerous, evil monster that does harm to human beings. Dragons kill people, make disaster, do damage and breathe fire. In the Medieval period, dragon represents evil or paganism, such as in the Book of Revelation, in the ninth sentence in chapter 12, Satan is called the great red dragon. Thus, dragon are used negatively in English and regarded as evil, as the proverb says 11e. "If you sow dragon's teeth, you will reap a crop of violence"; "to chase the dragon". And in the proverb $11 \mathrm{f}$. "A serpent must eat another serpent before he becomes a dragon", vicious people are dragons.

From the above comparison, we can see that dragon occupies a lofty status in the heart of Cheese people, which is treated as god who can do anything he wants to do. On the contrary, dragon is hated by western people, since dragon is considered as evil. Owing to the difference of national beliefs and religions, people have different understandings to dragon. In the Han dynasty, Buddhism was introduced from India. Up to now, it has become the largest religion in China. While in western countries like Britain which are a typically Christian country and its culture is deeply influenced by Bible. In China, dragon is an image of totem. It symbolizes auspiciousness, authority and nobility. In English, dragon is devil in Old Testament. Therefore, the metaphorical meanings of dragons are positive in Chinese, but negative in English.

\section{Proverbs of dog}

Dogs are domestic animals in both Western and oriental countries. In China, dogs are inferior animals; they are born to eat excrement. It is a natural instinct of dogs. Thus dogs are regarded as those bad people who can not change their bad behavior. The Chinese proverbs containing dogs are mostly negative. In the proverbs 12a. 狗走千里吃屎，狼走千 里吃人。-- Although a dog may travel a thousand leagues, it will still eat excrement; and although a wolf may travel a thousand leagues, it will still eat people, bad people are dogs. And because eating excrement is a natural instinct of dogs, people think that dogs' mouths are dirty, their teeth are ugly. As the proverb says $\underline{12 \mathrm{~b}}$. 狗嘴里吐不出象牙一Out of $a$ dog's mouth will never come ivory tusks. In the two proverbs $12 \mathrm{c}$. 狗眼看人低。-- From the lowly perspective of a dog's eyes, everyone looks short; and 12d. 狗不咬拜年的, 官不打送钱的。-- Just as dogs don't bite those who come to pay formal New Year's call, government officials don't beat those who send money, here snobbish people are dogs. In dog in the manger, dog refers to those people who are useless while they are still occupying the positions selflessly. In proverb 12e. 狗急跳墙, 人急悬梁-- Just as a cornered dog will leap over a wall, so a desperate person will hang himself from a roof beam, desperate situation is dog. 12f. 伸手不打垂死狗一A dead dog can't be propped up on top of a wall, good-for-nothing person is dead dog. In $12 \mathrm{~g}$. 饿狗不怕木棍一A hungry dog is not afraid of a wooden club, wicked people are hungry dogs and $12 \mathrm{~h}$. 饿狗咬人暗下口-When vicious dogs bite people they do so without warning implies dangerous people are hungry dogs.

However, western people treat dogs as friends, family members, soul mates. They like taking orders and pleasing their owners. And they are considered to be loyal animals. In this proverb $12 \mathrm{i}$. "If the dog barks, he gives the counsel", loyal people are dogs. People's friends are dogs in this proverb $12 \mathrm{j}$. Love me, love my dog. Dogs do not eat dogs. Here dogs are given human's emotion, and in $\underline{12 \mathrm{k}}$. "A good dog deserves a good bone", here people are dogs.

The above examples show that there are numerous metaphorical meanings of dogs both in English and Chinese. And most of the metaphorical meanings of dog in Chinese are negative while mostly positive in English. The differences mainly come from dogs' positions or status in China and western countries, concerning the different living styles and customs in these two cultures, such as pets. With the influence of local climate and environment, western people earn their life mainly by hunting, and dog is an important tool for production. Thus dog is not only a watch dog, but also a hunter, a partner and a friend in west. There are a great number of English proverbs which speak highly of dogs. For instance, every dog has its day. In China, most families have a dog. Instead of a pet, dogs are seen as livestock and the watch dog; they are used to guard the house and garden. To Chinese people, dogs are symbols of inferiority, and don't exist in compliments and praises. So most metaphorical meanings of dogs are derogatory.

\section{Proverbs of cat}

Cats are Chinese people's favorite pet. They like cats very much. As we all know, mice are hated by all the Chinese people, and cats are their natural enemies. Without cats, the mice will have a free rein to destroy anything. As the proverb says $13 \mathrm{a}$. 老猫不在家, 老鼠称大王一When the cat is away, the mice will play. Thus, mice have always been 
treated as bad ones while cats are regarded as justice and good person. Gradually, cats become the powerful ones, having the ability of leadership. In the proverb $\underline{13 \mathrm{~b}}$. 猫走鼠伸腰-When the cat has gone, the mice will straighten their backs, here people who has power or situated in high position is cat. In $13 \mathrm{c}$. 老鼠逢猫魂魄散, 羔羊遇虎骨笳酘 -- When the mice meet cats, their soul are scattered; lambs soften their muscles encountering tigers, and $13 \mathrm{~d}$. 猫也有权 看国王一A cat may look at a king; cats are people who want to be equal. In the proverb $\underline{13 \mathrm{e}}$. 猫有九命一A cat has nine lives, cat can always survive dangerous situations, and it reflects people who have strong vitality. In English, cats are often known as bad women who like speaking ill of others. As people often say she is a cat. According to the medieval superstitions, Satan could let himself be a black cat, and a witch often has a cat as her companion. (Evans: 1975) Thus cat presents evil things. In the proverb $\underline{13 \mathrm{f}}$. "The cat is out of the bag", traitors are cats. In $\underline{13 \mathrm{~g} .}$. "cats hide their paws" and $13 \mathrm{~h}$. "the cat shuts its eyes when stealing cream", here hypocritical people are cats. All cats are grey in the dark, cats are ordinary people. Western people may also take cats as pets, but many people think they are lazy and greedy. As the proverb says $13 \mathrm{i}$. "A cat in gloves catches no mice", and 13j. "The cat would eat fish, but would not wet her feet".

Above all, Chinese people take cats as a tool to catch the mice and cats are regarded as heroes while western people think cats are evil and greedy. People have different imaginations for the same kind of animal-- cat, and give a rich cultural connotation to cat. Therefore, the metaphorical meanings of cats in Chinese are often positive but in English are negative.

\section{Identical in Meanings But Different in Images}

In the development of human's long history, each nation has gradually developed its own unique folk custom and cultural heritage, and these things naturally will reflect in languages. Different nations can use different things to express the same pragmatic meanings, so do animals. So, from this perspective, people use different animals to express the same metaphorical meanings in English and Chinese. Here are some examples:

\section{Proverbs of tiger and lion}

In China, tiger is the monarch in the mountain, king of the beasts. Tiger is born and raised in China. People worship the image of tiger since the ancient time. There are lots of proverbs praise tiger. In the proverb 14a. 深山藏虎豹，狂野 喏麒麟-- The mountains hide tigers and leopards, and the wildness conceals unicorns, tigers are capable and talent people. The sayings and stories about tigers are very rich in China. For instance, the proverbs say $14 \mathrm{~b}$. 二虎相斗，必有 一伤—When two tigers fight, one is sure to be wounded; and 14c. 上小敢打虎, 下海敢擒龙一Dare to go up into the mountains to hunt tigers, and down to the sea to catch dragons. Tigers are precious animals. They are mainly scattered in Asia, especially in China's remote and border areas. West people have little chance to encounter the tigers. And people can't combine tiger with anything except that tiger is a dangerous and ferocious animal. And in the proverbs, tiger appears seldom, instead of using tigers, lions take its position. In west people's eyes, lions are huge in their bodies and are admired by many west people, and they are called king of the animals. The definition of lion in Collins Co build English Dictionary is "a person or a country that is considered to be strong and powerful, and which other people respect or fear". There are many proverbs containing lions, such as $\underline{14 \mathrm{~d}}$. regal as a lion, bold as a lion, majestic as a lion. Lion enjoys great reputation in western culture. British people even take lion as their national emblem. As tiger and lion are identical in meanings, in English, tiger's position are replaced by lion. For instance: 14e. a lion in the way一拦路虎 instead of 拦路狮; 最大的份额- the lion's share instead of the tiger's share; the lion's month should be translated as 虎穴 instead of 狮穴. And people also say 14f. 老虎屁股摸不得-Don't beard the lion, not saying beard the tiger.

\section{Proverbs of cattle and horse}

China is an agricultural country; to state the obvious, cattle takes a vital place in the agricultural society. Cattle are the indispensable tools which are used in traditional agricultural production. In China, cattle are used as holy spirits, and even been worshipped. People often relate cattle with simple, honest, strong, diligent, hard-working, and stubborn, etc. there are many Chinese proverbs based on cattle. For instance, 15a. 一头牛，半个家一A cattle equals to half family members; and $15 \mathrm{~b}$. 牛是种地的亚巴儿子-Cattle is the farmers' half dumb son. 15c. 牛有千斤之力一Have the power of heavy cattle, here implies cattle are very strong. Also, in the proverb $15 \mathrm{~d}$. 俯首甘为孺子牛一Head bowed, like a willing ox I serve the children, implying diligent, hard-working, sacrificing people. To English people, horses play an important role in the development of society. In ancient time, horses were used to do farming for people. They are used for traffic and are trained for war as well as race. People like horse and treat horses as their family members. And there are many proverbs containing horse. 15e. A good horse should never be spurred, and old wood is best to burn, old horse to ride. Horses can recognize the road and understand what their owners think. So they are considered to be talent. In this proverb $15 \mathrm{f}$. 马行千里, 无人不能自往。-- “Though it may run a thousand leagues, a horse won't go forward without someone leading it." Here talented people are horses. So is horse in the proverb $15 \mathrm{~g}$. 快马不用便催, 吹鼓不用 重锤。-- A swift horse needs no whipping and a good drum needs no heavy beating. In English and Chinese, horse and cattle relate to traditional farming respectively. Therefore, their meanings are similar. Often, people say Talk horse instead of Talk cattle; $15 \mathrm{~h}$. eat like a horse 食量如牛 not eat like a cattle; as strong as a horse 壮的像头牛 not as strong as a cattle. 
Above all, the differences in this kind of proverbs are mainly come from living environments. Living in different environment for a long time, people show the difference in the ways of expressing ideas, and the way of observing the world, difference in cosmic vision, aesthetics and beliefs in the west-east culture. Tiger and lion, cattle and horse, these two pairs of different animals, in each pair, the former ones are scarcely in west while the two animals take the similar roles, thus having the identical meanings.

\section{CONCLUSION}

From the above comparative analysis in the metaphorical meanings of animals between Chinese proverbs and English proverbs, we can see that metaphor exists in our daily life and structures our understanding of the world, our thought, culture and knowledge about life. Metaphor is a typical represent of ethnic culture. Besides, proverbs are not only information carriers, but also cultural carriers, reflecting different social culture. The author found that most of the proverbs are metaphors while a few of them are not. Animal proverbs are an important part of language, an indispensable element of culture. And the comparison of the three types of animal proverbs shows us the differences and similarities in living environments, living styles, religious beliefs, values, thinking mode and aesthetics of the two cultures. And their differences are also obvious. All in all, the research of animal proverbs has deepened our understanding: people in different cultures demonstrate the similarities or differences of different cultures by employing similar or different proverbs; different animal images can convey the same metaphorical meanings, and the same animal images can also convey the different metaphorical meanings. The metaphorical meanings of different animals are great achievements in English and Chinese. Understanding this phenomenon is helpful for us to promote communications and overcome language exchange barriers. We can also understand that study of proverbs is served for proverb teaching and learning.

\section{REFERENCES}

[1] Aristotle. (1954). Rhetoric and Poetics. New York: The Modern Library.

[2] Claire, Kramsch. (2000). language and culture. Shanghai: Shanghai Foreign Language Education Press.

[3] Honeck, R. P. (1997). A Proverb in Mind: The Cognitive Science of Proverbial Wit and Wisdom. Mahwah, NJ: Lawrence Erlbaum.

[4] Lakoff, G \& Johnson. (2003). Metaphors We Live By. Chicago: University of Chicago Press.

[5] Richards, I.A. (1936). The Philosophy of Rhetoric. London: Oxford University Press.

[6] Shu, Dingfang. (ed.) (2011). The Study of Metaphors and Metonymies. Shanghai: Shanghai Foreign Language Education Press.

[7] Wang, Dechun. (2000). Proverbs and Cultures in Chinese and English. Shanghai: Shanghai Foreign Language Education Press.

Jianwen Liu was born in Heze, China in 1979. He received his MA. degree in linguistics from Sichuan International Studies University, China in 2010.

$\mathrm{He}$ is currently a lecturer in the School of Foreign Languages, Wuhan Polytechnic University, Wuhan, China. He has published several papers on the topics of metaphors and metonymies, including The Studies of Metonymies under Cognitive Linguistics. His research interests include pragmatics and cognitive linguistics. 